\title{
Induction of mono-sex (male tilapia) population by inter-specific hybridization and hormonalsex revesal of Nile tilapia.
}

\author{
Nabil F. abd Al-Hakim ${ }^{1}$; Mohsen Saleh ${ }^{1}$; Ahmed Z. hegazi, Ayman Ibrahim \\ Khalfalla Aly ${ }^{1}$ and AlAzab M. Tahoun ${ }^{2}$ \\ 1- Animal Production Dept. faculty of Agriculture, Al-Azhar University, Cairo. \\ 2- Aquaculture Department, faculty of Fish Resources, Suez canal University, Suez, \\ Egypt
}

\section{ABSRRACT}

The present study. was planned with the aim to determine the optimal dose of oral administration of the androgen 17- $\alpha$ methyl testosterone (MT) for effective sex reversal, of Nile tilapia as well as comparing growth performance and feed utilization, proximate body composition and human food safety of hybrid blue tilapia Oreochromis aures X O. niloticus (T1), normal (T2) and sex reversed Nile tilapia, $O$. niloticus (T3 , T4 and T5). All treatment groups that received androgen, $17 \alpha$ methyl testosterone (MT) showed sex reversal in Oreochromis niloticus, with a significantly higher male proportion than female as compared to the control. The dose level of oral administration of $60 \mathrm{mg} \mathrm{MT/} \mathrm{kg} \mathrm{of} \mathrm{feed} \mathrm{for} 28$ days to Oreochromis niloticus resulted in maximum male sex ratio. The treatment groups (T2), that received $60 \mathrm{mg}$ MT for 28 days exhibited the best feed utilization in terms of FCR, PER, PPV\% and EU\% and in turn growth performance in terms of AFW, AWG, ADG, SGR (\%/ day)and survival rates. With regard to hman food safety, tilapias rapidly excrete ingested hormone, with MT levels falling to less than 1\% within 100 hours of withdrawing MT. Thus MT was not detectable in adult tilapias, which require a grow-out period of at least five to eight months to reach international marketable size.

From the results of the present study it can be concluded that, the use of $60 \mathrm{mg} / \mathrm{kg}$ MT produced statistically higher male sex percentage when done for 28 days post hatch with efficient feed and protein utilization and in turn attaining higher growth performance, survival rates and human safety.

Keywords: Hybridization, tilapia, 17- $\alpha$ methyl testosterone, sex reversal phase, growing phase, earthen ponds.

\section{INTRODUCTION}

Tilapias are of high importance in world fisheries, and are the second most important group of edible fishes in the world, next to the carps. Nile tilapia, Oreochromis niloticus accounted for a harvest of nearly 2.54 million tones in 2009 (FAO, 2011), second only to carp as a warm water food fish and exceeding the harvest of Atlantic salmon, Salmo salar, although, the value of the Atlantic salmon catch is more than twice that of the tilapia catch (Maclean et al., 2002). Although, native to Africa, tilapias are cultured in Asia and the Far East, and occupy two rather separate market niches, being a poor man's food fish in countries such as Israel and the southern United States (Maclean et al., 2002).One of the basic factors in tilapia aquaculture is that male fish grows bigger and faster than the female. Also, in order to avoid unwanted spawning in a production unit, an all-male population is preferred (Dan and Little, 2000 Carandang, 2007 and Abdul Mateen, 2007). There are several methods used to skew sex ratios and increase the percentage of males in a population. 
Several methods for controlling reproduction have been attempted such as interspecific hybridization, combined stocking with previous fishes, irradiation, monosex culture, cage culture, gynogenesis and sex reversal of all methods applied, hormonal sex reversal seems to be the most promising and acceptable techniques. Tilapia are easy to culture and reproduce, with rapid sexual maturation at 6/7 months from hatching and become marketable at this age. Nile tilapia is also an excellent laboratory animal that deserves to be studied (Maclean et al., 2002).

Synthetic androgens are used in fish culture as sex controlling agents and as growth promotors if energy is shut away from developing ovaries towards growth of somatic tissues. (El-Asaly, 2004 and Rizkallah et al., 2004). The more common method of generating mostly male populations is through the use of steroids fed to sexually undifferentiated fry. Newly hatched tilapias are still developing their gonads. Even though they are determined genotypically , their phenotype or morphological characteristics can still be altered. By exposing the fish to forms of testosterone or estrogen, the gonad can switch. Typically the desire is to produce all males, so methyltestosterone is included in the diet for several weeks when the fish starts eating. Utilizing MT at $60 \mathrm{mg} / \mathrm{kg}$ has consistently produced 95\% male sex ratio (Vorazayan and Petchrich, 2004; Nuanmanee et al., 2004). Studies involving sex reversal of Nile tilapia species using 17-amethyltestosterone is well documented. Numerous papers have reported that $60 \mathrm{mg} / \mathrm{kg}$ was found to induce mono-sex male populations (Nuanmanee et al., 2004; Vorasayan and Petchrich, 2004; Green and TeichertCoddington, 1994; Killian and Kohler, 1991 and Macintosh et. al, 1988). Hundred per cent sex reversal was achieved when both of these phases were fully completed. But in certain cases such as late commencement of MT treatment, shorter period of treatment, environmental factors, fish resistance etc. these phases could not be fully completed and a small proportion of fry showed an incomplete sex reversal stage intersex (Berger and Rothard, 1987).

\section{MATERIALS AND METHODS}

The present study was conducted in two phases (sex reversal and growth phase) by running two subsequent sets of experiments (phase I and phase II) in order to investigate the salt of hybridization between male Oreochromis aureus and female Nile tilapia O. niloticus and to determine the optimal dose rate of oral administration of androgen steroidal compound, $17 \alpha$-methyl testosterone (MT), for the sex reversal of Tilapia, O. niloticus. In the $1^{\text {st }}$ phase, the hormone $17 \alpha$-methyl testosterone was given at varying rates i.e. $0,60,80$ and $100 \mathrm{mg} \mathrm{MT} / \mathrm{kg}$ of feed.

The experimental treatments were subjected to be studied as the following scheme:

Table 1: The experimental treatments.

\begin{tabular}{|c|l|}
\hline Treatments & \\
\hline $\begin{array}{c}\text { T1, Hybrid , O. } \\
\text { aureus X O. niloticus }\end{array}$ & The hybridization between male Oreochromis aureus and female O. niloticus \\
\hline T2, MT $0 \mathrm{mg} / \mathrm{kg}$. & Oral administration, $17 \alpha$ - methyl testosterone (MT) @ 0 mg/ kg of feed for 28 days. \\
\hline T3, MT $60 \mathrm{mg} / \mathrm{kg}$. & Oral administration, $17 \alpha$-methyl testosterone (MT) @ 60mg/ kg of feed for 28 days. \\
\hline T4, MT $80 \mathrm{mg} / \mathrm{kg}$. & Oral administration, $17 \alpha$-methyl testosterone (MT)@ $80 \mathrm{mg} / \mathrm{kg}$ of feed for 28 days. \\
\hline T5, MT $100 \mathrm{mg} / \mathrm{kg}$. & Oral administration, $17 \alpha$-methyl testosterone (MT)@ $100 \mathrm{mg} / \mathrm{kg}$ of feed for 28 days. \\
\hline
\end{tabular}


The growth performance of experimental fish was monitored and the effect of hormone treatment proximate body composition and human food safety of tilapia was also determined.

\section{Phase I: Breeding and collection of Fry:}

A healthy group of Tilapia broodstock, Oreochromis aureus and O. niloticus, were identified and fed proteinatious feed prior to breeding. After one month, the healthy brooders were transferred to hapa-in-pond hatchery system for the purpose of breeding and fry production. Netting of the hapas was done after 21 days and the newly hatched fry were obtained from the mouth of female fish. These newly hatched fry were transferred carefully to a hapa system.

\section{Fry Stocking:}

48 hours after hatching, the frys were transferred to 2 sets of $101 \mathrm{~m}^{3}$ (1X1X1) circular fibreglass tanks ( 2 tanks for the offspring from the hybridization between male Oreocromis aureus X female $O$. niloticus, T1, dublicate tanks for the offspring of male and female $O$. niloticus represent the other experimental treatments T2, T3, T4 and T5 (0, 60, 80 and $100 \mathrm{mg}$ MT/ kg of feed. respectively. The frys were stocked at a density of 5000 fry per per tank for 28 days.

Feed with $40 \%$ crude protein and $17 \alpha$ - methyl testosterone was used in the experiment. The hormone was mixed with finely ground feed using the alcohol evaporation method (Guerroro, 1975). For the control treatment and growth phase, feed without hormone was used. Fry in each treatment group along with its replicate were fed formulated feed @10 \% of its body weight daily with the quantity increased daily based on anticipated growth rate and $100 \%$ survival and was adjusted weekly. Ration was fed three times a day approximately in equal amounts.

After 28 days of treatment, fish were harvested from each hapa and counted to estimate percent survival.

\section{Phase II: Transfer/stocking of fish:}

For growth studies, the fishes were transferred in fifteen earthen ponds having the dimensions $25 \times 10 \times 1.5$ meters each (triplicates group for the 5 experimental treatments). Before stocking, all ponds were sun dried for a period of fifteen days. The inlets of all ponds were properly screened with nylon wired gauze of fine mesh to avoid the entry of any intruders into, or exit of fish, from the ponds. The 15 experimental ponds were filled with water up to the level of $1.5 \mathrm{~m}$ and this level was maintained throughout the experimental period by the addition of water at frequent intervals. Fish were stocked at a rate of 4 fish $/ \mathrm{m}^{2}$ at total density of 1000 fish per pond.

\section{Feed preparation and regimen}

At the sex reversal phase (lasted for 28 days), at the stage of hormone treatment, or the fry resulting from the hybridization between the blue and Nile tilapia (T1) were fed the basic fry diet (Table ${ }^{2}$ ) without addition of testosterone), while the fry resulting from the mating between male and female Nile tilapia fed on the same basal diet supplemented with testosterone at 0, 60, 80 and $100 \mathrm{mg}$ methyl testosterone/ kg represent the second (T2), third (T3), fourth (T4) and fifth (T5) experimental treatments, respectively. The 0, 60, 80 and $100 \mathrm{mg}$ MT were dissolved into separate $200 \mathrm{ml}$ ethanol (95\%), sprayed onto two separate one kilogram fishmeal then mixed to produce a ratio of 40 and $60 \mathrm{mg} / \mathrm{kg}$ and air dried for 24 hours before feeding. The amount of feed given (grams) was fixed based on the assumed average Bodyweight per fry (grams) per week: week 1 (0.01), 2 (0.06), $3(0.20), 4(0.30)$. During the first, second, third and fourth week , fries were given feed equal to 30, 20, 
15 and $10 \%$ of their assumed bodyweight with a feeding rate of five, four, three and two times per day respectively. This regimen was applied on all experiments.

Table 2: Composition and proximate analysis of experimental adiets.

\begin{tabular}{|c|c|c|}
\hline$\underline{\text { Ingredients }} \quad \underline{\text { Diets }}$ & $\begin{array}{l}\text { 40\% crude protein } \\
\text { diet (Fry diet) }\end{array}$ & Formulated 25\% diet \\
\hline Fish meal (72 \% CP) & 30 & 7.00 \\
\hline Soybean meal (44 \% CP) & 35 & 25.00 \\
\hline Cotton seed meal & --- & 10.00 \\
\hline Corn gluten $(62 \% \mathrm{CP})$ & 10 & --- \\
\hline Corn grain & 22.5 & 12.00 \\
\hline Wheat bran & ---- & 32.00 \\
\hline Vegetable oil & 5 & 3.50 \\
\hline Di - Calcium phosphate & 2.00 & 2.50 \\
\hline Mollases & --- & 2.50 \\
\hline Anti-aflatoxin ${ }^{1}$ & 0.10 & 0.10 \\
\hline Vitamin C. $^{2}$ & 0.10 & 0.10 \\
\hline Min. \& Vit mixture ${ }^{2}$ & 0.30 & 0.30 \\
\hline$\frac{\text { Proximate analysis }}{\text { Dry matter }(\%)}$ & 90.0 & 89.0 \\
\hline Crude protein (\%) & 40.25 & 25.300 \\
\hline Ether extract (\%) & 9.25 & 6.25 \\
\hline Crude fibre $(\%)^{3}$ & 3.35 & 4.97 \\
\hline Ash (\%) & 8.95 & 10.1 \\
\hline Nitrogen free extract (\%) & 38.20 & 52.50 \\
\hline
\end{tabular}

\section{Phase II, grow-out phase (lasted for 210 days)}

Fishes were fed $25 \%$ crude protein formulated diet (Table 1) at 3\% body weight daily for the first 90 days started from stocking in earthen ponds and thereafter reduced to $2 \%$ body for 120 days, until the end of growth phase ( lasted for 210 days started on 1 April and ended on October 31, 2008). The fertilization of the pond was also done by using organic manure (Buffalo manure) @ $0.1 \mathrm{~g} \mathrm{~N} / 100 \mathrm{~g}$ of fish body weight daily. The quantity of both feed and manure was adjusted after every fortnight on the basis of freshly recorded data.

\section{Growth performance parameters:-}

The growth performance parameters are calculated according to the following equations:

- Average Weight Gain (AWG): -

$(\mathrm{AWG})=$ Average final weight $(\mathrm{g})-$ Average initial weight $(\mathrm{g})$

- Average Daily Gain (ADG): -

$(\mathrm{ADG})=[$ Average final weight $(\mathrm{g})-$ Average initial weight (g) $]$ / time (days)

- $\quad$ Specific Growth Rate (SGR \%/day): -

$(\mathrm{SGR} \% /$ day $)=100[\mathrm{Ln} \mathrm{Wt} 1-\mathrm{Ln} \mathrm{Wt} 0 / \mathrm{t}]$

Where: - Ln: normal log Wt 0: initial weight (g).

Wt 1: final weight (g) T: time of days.

Feed and protein utilization parameters:-

Feed and protein utilization parameters are calculated according to the following equations: - 
- $\quad$ Feed Conversion Ratio (FCR): -

FCR $=$ Total feed consumption/ weight gain .

- Feed efficiency (FE):-

$\mathrm{FE}=$ weight gain/ Total feed consumption

- Protein efficiency ratio (PER): -

PER = body weight gain $(\mathrm{g}) /$ protein intake $(\mathrm{g})$.

- $\quad$ Protein production value (PPV, \%): -

PPV $(\%)=100$ [Retained protein $(\mathrm{g}) /$ protein intake]

- Energy utilization (EU, \%): -

$\mathrm{EU}(\%)=100[$ Retained energy $(\mathrm{Kcal})] /$ energy intake $(\mathrm{Kcal})$

Analytical methods (diets and body chemical analyses):-

At the end of experiment, all fish were netted and weighed then representative samples of the experimental fish were taken at the beginning and at the end of the experiments for body chemical analyses. Fish samples were killed and kept frozen ($18^{\circ} \mathrm{C}$ ) until performing the body chemical analysis. Samples of the experimental fish diets (fry and on-growing) were taken, ground and stored in a deep freezer at $-18^{\circ} \mathrm{C}$ until proximate analysis. All of chemical analyses of fish and fish diets were determined according to A.O.A.C. (1990).

\section{Hormonal Analysis:}

The method applied for testosterone extraction in muscles was recommended by Umberger et al. (1963). Testosterone in the extract was estimated by enzyme linked immunosorbant assay (ELIZA) kit produced by the diagnostic system laboratories Incorporation.

\section{Statistical analysis:-}

Statistical analysis of each experiment was done using SAS Version 9 (SAS Institute, 2002) statistical package. Data were statistically analysed in one way analysis of variance procedure. Mean of treatments were compared by Duncan (1955) multiple range test. Duncan test $(\mathrm{p}<0.05)$ was used to compare means and $(\mathrm{F}<0.05)$ was considered for the variance analyses.

This study evaluated the potential effect of the hybridization between Oreochromis aureus ${ }^{\lambda} \mathrm{X}$ O. niloticus $q$ (T1); normal mating between Oreocromis niloticus $\widehat{\partial} \mathrm{X}$ O. niloticus $q$ (T2) and three different 17-a-Methyltestosterone (MT) dosages 60, 80 and $10 \mathrm{mg} \mathrm{MT/} \mathrm{kg} \mathrm{feed} \mathrm{to} \mathrm{produce} \mathrm{all} \mathrm{male} \mathrm{tilapia} \mathrm{fry} \mathrm{and} \mathrm{their} \mathrm{effects}$ on growth performance and feed utilization efficiency and the economic evaluation

\section{phase I, (sex reversal phase): \\ 1-Percentage of sex reversed fish}

\section{RESULTS AND DISCUSSION}

The evaluation of sex of Oreochromis niloticus under all the sex reversal treatments (T2, T3, T4 and T5) and the hybrid between Oreochromis aureus $X O$. niloticus (T1) was done at the end of the experiment. The following results were obtained.

The treatment No.2 showed a normal ratio of O. niloticus, with a $53.362 \pm$ $0.038 \%$ male and to $46.638 \pm 0.038 \%$ female ratio (Table 3 ), while all other treatments receiving 60, 80 and $100 \mathrm{mg}$ MT/ kg showed a greater and significantly higher $(\mathrm{P}<0.01)$ male proportion as compared to other experimental treatments (hybridization treatment, T1) and T2 (fry group received $0 \mathrm{mg} / \mathrm{kg}$ MT). 
Table 3: Effect of hybridization and 17 $\alpha$-Methyl Testosterone (MT) treatment for 28 days on sex ratio of hybrid Oreochromis aureusX O. niloticus and Nile tilapia fry on day 240 post hatching.

\begin{tabular}{|c|c|c|c|c|c|}
\hline \multirow{2}{*}{ Treatments } & \multirow{2}{*}{$\begin{array}{l}\text { Fish } \\
\text { No. }\end{array}$} & \multicolumn{2}{|c|}{ Male } & \multicolumn{2}{|c|}{ Female } \\
\hline & & No. & $\%$ & No. & $\%$ \\
\hline $\begin{array}{l}\text { T1, Hybrid tilapia } \\
\text { O. aureus X O. niloticus }\end{array}$ & $\begin{array}{c}782.000 \\
\pm \\
3.00 \\
\end{array}$ & $\begin{array}{c}595.3 \mathrm{c} \\
\pm \\
2.33\end{array}$ & $\begin{array}{c}76.130 \mathrm{c} \\
\pm \\
0.006\end{array}$ & $\begin{array}{c}186.667 \mathrm{~b} \\
\pm \\
0.667\end{array}$ & $\begin{array}{c}23.870 \mathrm{~b} \\
\pm \\
0.006\end{array}$ \\
\hline T2, MT 0 mg/ kg. & $\begin{array}{c}778.333 \\
\pm \\
3.333 \\
\end{array}$ & $\begin{array}{c}415.333 \mathrm{~d} \\
\pm \\
1.856\end{array}$ & $\begin{array}{c}53.362 \mathrm{~d} \\
\pm \\
0.038 \\
\end{array}$ & $\begin{array}{c}363.000 \mathrm{a} \\
\pm \\
1.528\end{array}$ & $\begin{array}{c}46.638 \mathrm{a} \\
\pm \\
0.038 \\
\end{array}$ \\
\hline T3, MT 60 mg/ kg. & $\begin{array}{c}785.667 \\
\pm \\
0.3333 \\
\end{array}$ & $\begin{array}{c}741.667 \mathrm{a} \\
\pm \\
3.333\end{array}$ & $\begin{array}{c}94.400 \mathrm{a} \\
\pm \\
0.145 \\
\end{array}$ & $\begin{array}{c}42.667 \mathrm{~d} \\
\pm \\
1.764\end{array}$ & $\begin{array}{c}5.431 \mathrm{~d} \\
\pm \\
0.224\end{array}$ \\
\hline T4, MT 80 mg/ kg. & $\begin{array}{c}782.333 \\
\pm \\
3.667 \\
\end{array}$ & $\begin{array}{c}741.667 \mathrm{a} \\
\pm \\
3.333 \\
\end{array}$ & $\begin{array}{c}94.802 \mathrm{a} \\
\pm \\
0.018\end{array}$ & $\begin{array}{c}40.667 \mathrm{~d} \\
\pm \\
0.333\end{array}$ & $\begin{array}{c}5.198 \mathrm{~d} \\
\pm \\
0.018\end{array}$ \\
\hline T5, MT 100mg/ kg. & $\begin{array}{c}783.333 \\
\pm \\
1.667\end{array}$ & $\begin{array}{c}731.667 \mathrm{~b} \\
\pm \\
1.202\end{array}$ & $\begin{array}{c}93.405 \mathrm{~b} \\
\pm \\
0.144\end{array}$ & $\begin{array}{c}51.000 \mathrm{c} \\
\pm \\
0.577\end{array}$ & $\begin{array}{c}6.510 \mathrm{c} \\
\pm \\
0.062\end{array}$ \\
\hline
\end{tabular}

Means in the same column having different letters are significantly $(\mathrm{P} \leq 0.05)$ different

Macintosh et al. (1988) found that administration of $40 \mathrm{mg} / \mathrm{kg}$ MT had a higher male sex reversal than $60 \mathrm{mg} / \mathrm{kg}$, when they conducted the experiment in clear water tanks. They further observed the depressant effects (abnormally enlarged ovaries in females and testicular degeneration in some males which lowered the GSI) of MT when used in a higher dosage $(60 \mathrm{mg} / \mathrm{kg}$ ). Abucay and Mair (1997) were consistently successful in sex reversal of tilapia species using $40 \mathrm{mg} / \mathrm{kg}$ MT dosage under closed water system. On the other hand, Pongtana et al. (2004) utilized $60 \mathrm{mg} /$ $\mathrm{kg}$ MT to achieve $97.9+1.5 \%$ male sex tilapia for a period of 21 days. This practice is currently used in commercial mass production of sex reversed Nile tilapia fry. The incidence of intersex was also consistently observed especially in the MT treatments, which further suggests that the presence of readily available food in an earthen pond affected the efficiency of sex reversal using MT. It is also important to note that MT is an aromatizable androgen which means it can be converted into estrogen by an enzyme produced in the liver called aromatase (Alfonso and Leboute, 2003). The present results agreed with those of Saad and Samira (1999) who respited that there are no intersex individuals in MT 28 days. On the other hand (El-Halawany, 2002 and Hammad (2003) and Al-Asaly,( 2004) found inter-sex individuals among O. niloticus fry fed with the MT dose $60 \mathrm{mg}$ and kept at the same exposure period (28 days). Romerio et al. (2000) used different dose rates of 17- $\alpha$ methyl testosterone in two diets having $40 \%$ crude protein for a total of 9600 Nile tilapia fries. Seven days post hatching fry received the MT orally mixed in diets for 45 days. The result of chisquare test of the frequency data of males and females after the treatment and of analysis of histological and macroscopic characteristics showed that the numbers of males obtained by all the MT treatments was higher than the control groups and the dose of $60 \mathrm{mg} \mathrm{MT} / \mathrm{kg}$ of diet was more efficient, resulting in $98 \%$ of males.

Guerrero (1975) used much lower MT dose rate and treated tilapia fry for 28 days with a dietary level of $30 \mathrm{mg} \mathrm{MT} / \mathrm{Kg}$ of feed and claimed, based on the evidence of external sexual characters, that $95-98 \%$ of fish produced were males. Guerrero and Guerrero (1988) also proposed that $30 \mathrm{mg}$ of MT/ $\mathrm{kg}$ of diet for 21 days as the most promising dose resuled in 99\% male O. niloticus with this treatment on commercial scale. Boeck et al. (1992) produced 98\% males when feeding $60 \mathrm{mg} \mathrm{MT} / \mathrm{kg}$ for 30 days at 21-23 ${ }^{\circ}$ C. Vera-Cruz and Mair (1994) treated Nile tilapia with $30 \mathrm{mg}$ of MT/ $\mathrm{kg}$ of diet fed at $20 \%$ body weight for 25 days and obtained $98.4 \%$ males in tank and 
95.4\% males in hapas but with 60 mg MT treatment they obtained 99\% males under similar conditions.

\section{Growth performance and survival rates:-}

Growth performance of tilapia groups as affected by different experimental treatments are given in Table (4). The data indicated that, there are significant $(\mathrm{P} \leq 0.05)$ differences among different tilapia groups in terms of Average final weight (AFW), average weight gain (AWG), average daily gain (ADG) and specific growth rate (SGR, \%/ day), while the differences found among survival rates as affected by the experimental treatments were insignificant.

The highest AWG ( 332.483 \# 7.753g ) and ADG (1.387 \# 0.032g/ day) ware observed in T3 (60 mg MT/ kg)while The lowest AWG (249.486 $\pm 1.66 \mathrm{~g})$ and ADG (1.040 $\pm 0.012 \mathrm{~g}$ ) were observed in T2 (normal mating Nile tilapia). The SGR values ranged between $3.016 \pm 0.032$ and $3.127 \pm 0.014 \%$ / day for T2 and T3, respectively. Some authors are of the view that any improved growth of androgen treated tilapia is more related to the superior growth of males than the more classical anabolic response related to enhanced protein synthesis and increase in muscle mass (Abdul Mateen, 2007). Moreover, the primary indicator of growth performance in fish is fresh body weight. In this study, the final body weight and net fish production of $O$. niloticus, after a period of 240 days of grow out phase, showed a marked increase for all the dose rates of treatments (T3, T4 and T5) of MT than the T1 (the hybridization between blue tilapia, Oreochromis aureus and female Nile tilapia, O. niloticus) and T2 (untreated Nile tilapia group), clearly indicating that MT treatment enhances the growth rate and biomass production of Nile tilapia very efficiently. The treatment group that received $60 \mathrm{mg}$ MT/ $\mathrm{kg}$ of feed for 28days (having the highest male percentage of $94.40 \%$ ) showed the highest average weight gain. Concerning the data on survival rates at day 240 post hatching (Table 4), it can be noted that, no significant differences were found among fish groups as affected by the experimental treatments.

Table 4:

\begin{tabular}{|c|c|c|c|c|c|c|}
\hline Treatments & $\begin{array}{l}\text { Average } \\
\text { Initial } \\
\text { weight }\end{array}$ & $\begin{array}{c}\text { Average } \\
\text { final weigh }\end{array}$ & Weight gain & $\begin{array}{l}\text { Average } \\
\text { daily gain }\end{array}$ & $\begin{array}{c}\text { Specific } \\
\text { growth rate }\end{array}$ & $\begin{array}{c}\text { Survival } \\
\text { rate }\end{array}$ \\
\hline $\begin{array}{c}\text { T1, Hybrid } \\
\text { tilapia } \\
\text { O. aureus X O. } \\
\text { niloticus }\end{array}$ & $\begin{array}{c}0.177^{\mathrm{a}} \\
\pm \\
0.003\end{array}$ & $\begin{array}{c}285.00 \mathrm{c} \\
\pm \\
2.89\end{array}$ & $\begin{array}{c}285.000 \mathrm{c} \\
\pm \\
2.887\end{array}$ & $\begin{array}{c}1.187 \mathrm{c} \\
\pm \\
0.012\end{array}$ & $\begin{array}{c}3.078 \mathrm{ab} \\
\pm \\
0.009\end{array}$ & $\begin{array}{c}97.750 \mathrm{a} \\
\pm \\
0.375\end{array}$ \\
\hline $\begin{array}{l}\text { T2, MT } 0 \text { mg/ } \\
\text { kg. }\end{array}$ & $\begin{array}{c}0.180 \mathrm{a} \\
\pm \\
0.011\end{array}$ & $\begin{array}{c}249.67 \mathrm{~d} \\
\pm \\
2.906 \\
\end{array}$ & $\begin{array}{c}249.486 \mathrm{~d} \\
\pm \\
1.66 \\
\end{array}$ & $\begin{array}{c}1.040 \mathrm{~d} \\
\pm \\
0.012\end{array}$ & $\begin{array}{c}3.016 \mathrm{~b} \\
\pm \\
0.032\end{array}$ & $\begin{array}{c}97.292 \mathrm{a} \\
\pm \\
0.417\end{array}$ \\
\hline $\begin{array}{c}\text { T3, MT } 60 \text { mg/ } \\
\text { kg. }\end{array}$ & $\begin{array}{c}0.183 \mathrm{a} \\
\pm \\
0.003\end{array}$ & $\begin{array}{c}333.67 \mathrm{a} \\
\pm \\
6.110\end{array}$ & $\begin{array}{c}332.483 \mathrm{a} \\
\pm \\
7.753 \\
\end{array}$ & $\begin{array}{c}1.387 \mathrm{a} \\
\pm \\
0.032\end{array}$ & $\begin{array}{c}3.127 \mathrm{a} \\
\pm \\
0.014\end{array}$ & $\begin{array}{c}98.208 \mathrm{a} \\
\pm \\
0.042\end{array}$ \\
\hline $\begin{array}{c}\text { T4, MT } 80 \text { mg/ } \\
\text { kg. }\end{array}$ & $\begin{array}{c}0.193 \mathrm{a} \\
\pm \\
0.003\end{array}$ & $\begin{array}{c}308.000 \mathrm{~b} \\
\pm \\
4.409\end{array}$ & $\begin{array}{c}308.140 \mathrm{~b} \\
\pm \\
4.413\end{array}$ & $\begin{array}{c}1.284 \mathrm{~b} \\
\pm \\
0.018\end{array}$ & $\begin{array}{c}3.073 \mathrm{ab} \\
\pm \\
0.013\end{array}$ & $\begin{array}{c}97.791 \mathrm{a} \\
\pm \\
0.458\end{array}$ \\
\hline $\begin{array}{c}\text { T5, MT 100mg/ } \\
\text { kg. }\end{array}$ & $\begin{array}{c}0.190 \mathrm{a} \\
\pm \\
0.005\end{array}$ & $\begin{array}{c}296.667 \text { bc } \\
\pm \\
4.410\end{array}$ & $\begin{array}{c}296.477 \text { bc } \\
\pm \\
4.415 \\
\end{array}$ & $\begin{array}{c}1.235 \mathrm{~b} \\
\pm \\
0.018\end{array}$ & $\begin{array}{c}3.064 \mathrm{ab} \\
\pm \\
0.019 \\
\end{array}$ & $\begin{array}{c}97.917 \mathrm{a} \\
\pm \\
0.208\end{array}$ \\
\hline
\end{tabular}


Our results may be confirmed by those of Wichai, (1987); Al-Asaly, (2004) who found no significant differences in survival rates among treated and un-treated fish groups. On the contrary, Mangawaya, (1986) found that survival rates were higher in the control than $30 \mathrm{mg} / \mathrm{kg}$ treated groups. In this connection Pandian and Sheela, (1995) concluded that in general a treatment involving synthetic steroid resulted in higher mortality of most fish species, thus masculinization with the male heteroametic species may lead to lower survival rates. It can be noted that, as tilapia male ratio increased, the growth rates would be higher as compared to female tilapia. In this connection, Toguyeni et al. (2002) cited that male tilapia grow faster than females, long before sexual maturity. This better growth in males could not be attributed only to higher allocation of metabolic energy into gametogenesis in females as compared to males. The higher growth of males as compared to female tilapia broodstock was confirmed by the findings of Beardmore et al. (2001) who stated that, the use of male tilapia fish is intrinsically desirable in a variety of fish species in a range of aquaculture production systems. The potential advantages sought from their use may include one or more of the following features: achievement of higher average growth rate, elimination of reproduction, reduction of sexual territorial behavior, reduction of variation in harvest size, and reduction of risk of environmental impact resulting from escapes of exotic species. Dan and Little (2000), while observing the culture performance of monosex and mixed sex culture of three strains of Nile tilapia reported that among the three tilapia strains, the GIFT fish attained a significantly $(\mathrm{P}<0.01)$ larger individual final weight (387.7 $\mathrm{g}$ in ponds and $410.6 \mathrm{~g}$ in cages) compared to the Thai strain (351.6 $\mathrm{g}$ in ponds and $373.2 \mathrm{~g}$ in cages) and Veit strains (359.5 $\mathrm{g}$ in ponds and $350.3 \mathrm{~g}$ in cages). They further narrated that overall, monosex fish of three strains grew significantly faster than mixed-sex fish. On the contrary, Soto (1992) and Vera-Cruiz and Maire (1994) reported no effect of hormone on growth in O. niloticus. Pechsiri and Yakupitiyage (2005), while working on the comparative study of growth and feed utilization efficiencies of sex reversed diploid and triploid Nile tilapia reported no significant difference in final body weight of these sex reversed species.

\section{protein and feed uilization:-}

As shown in Table (5) it can be noted that, there were significanto(.B5) differences among different experimental treatments in terms of feed intake, feed conversion ratio (FCR), protein efficiency ratio (PER), protein productive value (PPV\%) and energy utilization (EU\%) as affected by different experimental treatments.

Table 5: Protein and feed utilization parameters as affected by experimental hybridizations and hormonal treatments

\begin{tabular}{|c|c|c|c|c|c|c|}
\hline Treatments & $\begin{array}{l}\text { Feed } \\
\text { intake }\end{array}$ & $\begin{array}{l}\text { Weight } \\
\text { gain }\end{array}$ & $\begin{array}{c}\text { Feed } \\
\text { conversion ratio }\end{array}$ & $\begin{array}{l}\text { Protein } \\
\text { efficiency ratio }\end{array}$ & $\begin{array}{c}\text { Protein } \\
\text { productive } \\
\text { value }\end{array}$ & $\begin{array}{c}\text { Energy } \\
\text { utilization }\end{array}$ \\
\hline $\begin{array}{c}\text { T1, Hybrid tilapia } \\
\begin{array}{c}\text { O. aureus X O. } \\
\text { niloticus }\end{array}\end{array}$ & $\begin{array}{c}571.667 \mathrm{c} \\
\pm \\
7.265 \\
\end{array}$ & $\begin{array}{c}285.00 \mathrm{c} \\
\pm \\
2.89 \\
\end{array}$ & $\begin{array}{c}2.008 \mathrm{~b} \\
\pm \\
0.046\end{array}$ & $\begin{array}{c}2.189 \mathrm{~b} \\
\pm \\
0.050\end{array}$ & $\begin{array}{c}43.858 \mathrm{~b} \\
\pm \\
0.748 \\
\end{array}$ & $\begin{array}{c}21.734 \mathrm{~b} \\
\pm \\
0.358 \\
\end{array}$ \\
\hline T2, MT 0 mg/ kg. & $\begin{array}{c}623.33 \mathrm{a} \\
\pm \\
12.019 \\
\end{array}$ & $\begin{array}{c}249.67 \mathrm{~d} \\
\pm \\
2.906 \\
\end{array}$ & $\begin{array}{c}2.500 \mathrm{a} \\
\pm \\
0.073\end{array}$ & $\begin{array}{c}1.760 \mathrm{c} \\
\pm \\
0.053\end{array}$ & $\begin{array}{c}35.392 \mathrm{c} \\
\pm \\
1.144 \\
\end{array}$ & $\begin{array}{c}17.639 \text { c } \\
\pm \\
0.589 \\
\end{array}$ \\
\hline T3, MT 60 mg/ kg. & $\begin{array}{c}583.67 \text { bc } \\
\pm \\
13.38\end{array}$ & $\begin{array}{c}333.67 \mathrm{a} \\
\pm \\
6.110\end{array}$ & $\begin{array}{c}1.755 \mathrm{c} \\
\pm \\
0.046\end{array}$ & $\begin{array}{c}2.506 \mathrm{a} \\
\pm \\
0.064\end{array}$ & $\begin{array}{c}51.475 \mathrm{a} \\
\pm \\
1.429\end{array}$ & $\begin{array}{c}25.954 \mathrm{a} \\
\pm \\
0.727\end{array}$ \\
\hline T4, MT 80 mg/ kg. & $\begin{array}{c}606.67 \mathrm{ab} \\
\pm \\
6.009\end{array}$ & $\begin{array}{c}308.000 \mathrm{~b} \\
\pm \\
4.409\end{array}$ & $\begin{array}{c}1.970 \mathrm{~b} \\
\pm \\
0.042\end{array}$ & $\begin{array}{c}2.231 \mathrm{~b} \\
\pm \\
0.049\end{array}$ & $\begin{array}{c}45.408 \mathrm{~b} \\
\pm \\
1.263\end{array}$ & $\begin{array}{c}22.879 \mathrm{~b} \\
\pm \\
0.676\end{array}$ \\
\hline T5, MT 100mg/ kg. & $\begin{array}{c}575.67 \mathrm{c} \\
\pm \\
2.962\end{array}$ & $\begin{array}{c}296.667 \text { bc } \\
\pm \\
4.410\end{array}$ & $\begin{array}{c}1.942 \mathrm{~b} \\
\pm \\
0.020\end{array}$ & $\begin{array}{c}2.262 \mathrm{~b} \\
\pm \\
0.023\end{array}$ & $\begin{array}{c}45.490 \mathrm{~b} \\
\pm \\
0.908\end{array}$ & $\begin{array}{c}22.925 \mathrm{~b} \\
\pm \\
0.234\end{array}$ \\
\hline
\end{tabular}

Means in the same column having different letters are significantly $(\mathrm{P} \leq 0.05)$ different 
In this experiment, an attempt was made to establish a relationship between the hormonal sex reversal on one side and the efficiency to utilize the feed and protein on the other side, in order to assess the best feeding practice.

Better survival rate was also consistent in MT treatments, which were above $90 \%$. The FCR was comparable as was in the earthen pond. The MT treatment did not improve FW and FCR which suggests that anabolism as theorized with the use of MT was not a factor. This was on contrary when done in the earthen pond because of the presence of natural food compensated for the lack in the feed mixture.

\section{Body proximate composition:-}

Data on the chemical body composition of tilapia as affected by experimental treatments are shown in table (6). The differences among treatments were significant $(\mathrm{P} \leq 0.05)$ in terms of body dry matter, crude protein, ether extract and the body ash content .

Table 6: Body chemical composition of tilapia, parameters as affected by experimental hybridization and hormonal treatments.

\begin{tabular}{|c|c|c|c|c|c|}
\hline \multirow{2}{*}{ Treatments } & \multirow{2}{*}{$\begin{array}{l}\text { Dry matter } \\
(\%)\end{array}$} & \multirow{2}{*}{ Moisture } & \multicolumn{3}{|c|}{ On dry matter (\%) } \\
\hline & & & $\mathrm{CP}$ & $\mathrm{EE}$ & Ash \\
\hline $\begin{array}{c}\text { T1, Hybrid tilapia } \\
\text { O. aureus X O. } \\
\text { niloticus }\end{array}$ & $\begin{array}{c}31.433 \mathrm{~b} \\
\pm \\
2.603 \\
\end{array}$ & $\begin{array}{c}68.567 \mathrm{a} \\
\pm \\
0.002 \\
\end{array}$ & $\begin{array}{c}63.767 \mathrm{ab} \\
\pm \\
1.333 \\
\end{array}$ & $\begin{array}{c}18.466 \mathrm{~b} \\
\pm \\
0.002 \\
\end{array}$ & $\begin{array}{c}16.867 \mathrm{~b} \\
\pm \\
0.012 \\
\end{array}$ \\
\hline T2, MT 0 mg/ kg. & $\begin{array}{c}31.713 \mathrm{ab} \\
\pm \\
0.107 \\
\end{array}$ & $\begin{array}{c}68.287 \mathrm{ab} \\
\pm \\
0.001 \\
\end{array}$ & $\begin{array}{c}63.433 \mathrm{~b} \\
\pm \\
0.106 \\
\end{array}$ & $\begin{array}{c}18.667 \mathrm{~b} \\
\pm \\
0.006 \\
\end{array}$ & $\begin{array}{c}16.933 \mathrm{~b} \pm \\
0.009\end{array}$ \\
\hline T3, MT 60 mg/ kg. & $\begin{array}{c}32.433 \mathrm{a} \\
\pm \\
0.288\end{array}$ & $\begin{array}{c}67.567 \mathrm{~b} \\
\pm \\
0.002 \\
\end{array}$ & $\begin{array}{c}63.333 \mathrm{~b} \\
\pm \\
0.009\end{array}$ & $\begin{array}{c}19.267 \mathrm{a} \\
\pm \\
0.006\end{array}$ & $\begin{array}{c}17.667 \mathrm{a} \\
\pm \\
0.002 \\
\end{array}$ \\
\hline T4, MT 80 mg/ kg. & $\begin{array}{c}31.733 \mathrm{ab} \\
\pm \\
0.609 \\
\end{array}$ & $\begin{array}{c}68.267 \mathrm{ab} \\
\pm \\
0.033 \\
\end{array}$ & $\begin{array}{c}64.133 \mathrm{ab} \\
\pm \\
0.032 \\
\end{array}$ & $\begin{array}{c}19.467 \mathrm{a} \\
\pm \\
0.012 \\
\end{array}$ & $\begin{array}{c}17.700 \mathrm{a} \\
\pm \\
0.001 \\
\end{array}$ \\
\hline T5, MT 100mg/ kg. & $\begin{array}{c}31.133 \mathrm{~b} \\
\pm \\
0.577 \\
\end{array}$ & $\begin{array}{c}68.867 \mathrm{a} \\
\pm \\
0.006 \\
\end{array}$ & $\begin{array}{c}64.633 \mathrm{a} \\
\pm \\
0.441 \\
\end{array}$ & $\begin{array}{c}19.633 \mathrm{a} \\
\pm \\
0.009 \\
\end{array}$ & $\begin{array}{c}17.867 \mathrm{a} \\
\pm \\
0.003 \\
\end{array}$ \\
\hline
\end{tabular}

Means in the same column having different letters are significantly $(\mathrm{P} \leq 0.05)$ different.

The results of proximate body composition as affected hybridization and different MT treatments revealed that there was a marked effect of sex reversal treatment on the body composition of fish. Statistically, the total fat, ash and carbohydrate content showed a highly significant difference among different treatments. The crude protein and ash contents were not significantly affected by the experimental treatments. The sex reversed $O$. niloticus group (T5) with the highest moisture (68.867 \%) had the highest lipid content (19.633\%). However, Pechsiri and Yakupitiyage (2005) compared the growth and feed utilization efficiency of sex reversed Nile tilapia and found maximum moisture content (82.8\%) in meat of fish having the lowest (2.4\%) lipid content. These results are also in disagreement with results Mamun et al.( 2004), who reported that a sex reversed O. niloticus strain with the highest moisture (69.7\%) in meat had the lowest lipid content (7.15\%) in comparison to other two experimental strains. In this study, percentage of total fat concentration remained higher in all MT treated fish groups (T3, T4 and T5) than in the untreated groups (T1 and T2). There was a trend towards accumulation of fat that was correlated with MT concentration. Comparable results were obtained by Abdul Mateen, (2007). Ash content was higher in sex reversed groups than in normal hybrid tilapia and Nile tilapia. The untreated groups (T1 and T2) showed the lowest (16.867 and 16.933) ash contents; while the highest ash 
content (17.867\%) was recorded for the treatment group that received $100 \mathrm{mg}$ MT for 28 days. Similar results were reported by Pechsiri and Yakupitiyage (2005) who found 4.6\% ash in the flesh.

\section{Human food safety}

Data on the Whole body and muscles MT concentrations of tilapia, parameters as affected by some experimental hybridization and hormonal treatments are shown in table (7). No significant differences were found among T3, MT $60 \mathrm{mg} / \mathrm{kg}$ and untreated groups (hybrid tilapia, T1) and Nile tilapia received $0 \mathrm{MT} \mathrm{mg} / \mathrm{kg}$ (T2). In this connection, tilapias rapidly excrete ingested hormone, with MT levels falling to less than 1\% within 100 hours of withdrawing MT. Thus MT is not detectable in adult tilapias, which require grow-out period of at least five months to reach international marketable size. Johnstone et al. (1983) reported on the elimination rate of MT in both trout and tilapia. They found that whole fish body levels of MT were not detectable only 100 hours after withdrawal of the hormone-treated diet. In the fish carcass, MT was undetectable after only 50 hours of hormone withdrawal. Moreover, in experimental studies on tilapia fillets, Green and Teichert (2000) estimated the concentration of MT in one portion of edible tissue (57 to 143g skinless fillet) to be in the low parts per trillion range, or 1.2- 3.4 ng MT. Again, these figures were based on a 21 day withdrawal period and did not take into consideration the metabolism and excretion associated with a longer withdrawal period. Based on the scientific evidence that MT is rapidly eliminated from fish, there is no possibility that MT will persist in adult fish after the several months required for farmed tilapias to reach marketable size.

Table 7: Whole body and muscles MT concentrations of tilapia, parameters as affected by experimental hybridization and hormonal treatments.

\begin{tabular}{|c|c|c|}
\hline Treatments & $\begin{array}{c}\text { Whole body MT } \\
\text { concentration ng/g }\end{array}$ & $\begin{array}{c}\text { Muscles MT } \\
\text { concentration ng/g }\end{array}$ \\
\hline $\begin{array}{c}\text { T1, Hybrid tilapia } \\
\text { O. aureus X O. niloticus }\end{array}$ & $6.430 \mathrm{~b} \pm 0.357$ & $1.880 \mathrm{~b} \pm 0.121$ \\
\hline T2, 0 MT mg/ kg. & $6.120 \mathrm{~b} \pm 0.323$ & $1.850 \mathrm{~b} \pm 0.145$ \\
\hline T3, 60 MT mg/ kg. & $6.520 \mathrm{~b} \pm 1.146$ & $1.730 \mathrm{~b} \pm 0.081$ \\
\hline T4, 80 MT mg/ kg. & $7.980 \mathrm{~b} \pm 1.698$ & $3.130 \mathrm{a} \pm 0.336$ \\
\hline T5, 100 MT mg/ kg. & $11.270 \mathrm{a} \pm 0.743$ & $3.410 \mathrm{a} \pm 0.457$ \\
\hline
\end{tabular}

\section{CONCLUSION}

The use of $60 \mathrm{mg} / \mathrm{kg}$ MT produced statistically higher male sex percentage when done for 28 days post hatch with efficient feed and protein utilization and in turn attaining higher growth performance and survival rates. Moreover, Tilapias rapidly excrete ingested hormone, with MT levels falling to less than $1 \%$ within 100 hours of withdrawing MT. Thus MT is not detectable in adult tilapias, which require a grow out period of at least five months to reach marketable size. 


\section{REFERENCES}

A.O.A.C. Association of Official Agricultural Chemists (1990). Official methods of analysis. $15^{\text {th }}$ Ed. Published by the A.O.A.C., Benjamin Francklin Station, Washington. D. C., USA.

Abd el-Aziz, M. A. (2002). Field study on the effect of dferent times of exposure during hormonal production of mono-sex tilapia on the growth rates and health condition during the cultureseason .Egyptian soc. Animal Reprod. Fert. Nutr. Association. Giza 27 Feb.

Abdul Mateen (2007). Effect of androgen on the sex reversal, growth and meat quality of tilapia, Oreochromis niloticus. Ph. D. Thesis. University of Agriculture, Faisalabad

Abucay, J. S. and G. C. Mair. 1997. Hormonal sex reversal of tilapias: implications of hormone treatment application in closed water Systems. Aqu. Res 28: 841-845.

Al-Asaly, A.M. A. (2004). Some studies on steroid induced mono-sex Nile tilapia. M. Sc. Tesis. Faculty of Vet. Medicine. Zagazig University.

Alfonso, L.O.B. and E. M. Leboute. 2003. Sex reversal in Nile tilapia: Is it possible to produce all-male stocks through immersion in androgens? World Aquaculture. Sep 16-19.

Berger, A. and S. Rothbard 1987. Androgen induced sex reversal of red tilapia fry stocked in cages within ponds. Bamidgeh, 39 (2): 49-57.

Bocek, A.J., R. P. Phelps and T.J. Pompa. (1992). Effect of feeding frequency on sex reversal and growth of Nile tilapia Oreochromis niloticus. J. of App Aqu, 1: 97103.

Carandang, R. P. J.R. (2007). Effect of butea superba and 17-a-methyltestosterone (MT) on sex reversal and some growth parameters in three strains (red, ghana and chitralada) of Nile tilapia (Oreochromis niloticus, L.Ph. D thesis. Maejo University.

Dan, N.C. and D.C. Little. (2000). The culture performance of monosex and mixedsex new-season and overwintered fry in three strains of Nile tilapia (Oreochromis niloticus) in northern Vietnam. Aquaculture, 184: 221-231.

Duncan, D. B. (1955). Multiple range and multiple F-test. Biometrics, 11: 1-42.

El-Halawany, H. M. (2002). Effect of treatment with 17 $\alpha$-Methyl Testosterone (MT) on growth performance, feed and nutrient utilization of Nile tilapia (Oreocromis niloticus). M V. Sc. Thesis (Animal Production, Fish Nutrition). Fac. Agric. Alex. University.

FAO, (2011). The State of World Fisheries and Aquaculture, Food and Agriculture Organization, Rome, Italy.

Green B.W. and D.R. Teichert-Coddington. (1994). Growth of Control and Androgen-treated Nile Tilapia, Oreochromis niloticus (L.), during Treatment, Nursery and Grow-out Phases in Tropical Fishponds. Aquaculture and Fisheries Management. 25: 613-621.

Green, B.W. and D.R. Teichert-Coddington. (2000). Human Food Safety and Environmental Assessment of the Use of 17-a-Methyltestosterone to produce Male Tilapia in the United States. Journal of the World Aquaculture Society. 31: 337- 357.

Guerrero R.D. III. (1975). Use of androgens for production of all male Tilapia aurea (Steindachner) Trans. Amer. Fish. Soci., 2: 342-347.

Guerrero R.D. III. and Guerrero L.A. (1988). Feasibility of commercial production of Nile tilapia fingerlings in Philippines. In: The Second Symposium on Tilapia in 
Aquaculture. ICLARM Conference Proceedings (ed. by R.S.V. 137 Pullin, T. Bhukaswan, K. Tonguthi and J. L. Macleen), International Center for Living Aquatic Resource Management, Manila, Philippines, 15: 183-186.

Johnstone R., Macintosh D. J. and Wright R. S. (1983). Elimination of orally administered 17 a Methyltestosterone by Oreochromis mossambicus (tilapia) and Salmo gairdneri (rainbow trout) juveniles Aquaculture 35 249-257.

Killian, H. S. and C. C. Kohler. 1991. Influence of 17-a-methyltestosterone on red tilapia under two thermal regimes. Joumal of the World Aquaculture Society 22: 83-94.

Macintosh, D.J., T.B. Singh, D.C. Little and P. Edwards. 1988. Growth and Sexual Development of 17-a-Methyltestosterone-treated Nile Tilapia (Oreochromis niloticus) Reared in Earthen Ponds. Proceedings in The $2^{\text {nd }}$ International Symposium on Tilapia in Aquaculture, ICLARM Conference 15: 623 January 1990.

Maclean N, Rahman MA, Sohm F, Hwang G, Iyengar A, Ayad H, Smith A, Farahmand H (2002). Transgenic tilapia and the tilapia genome. Gene, 295: 265277.

Mamun, S.M., U. Focken, G. Frances and K. Becker. 2004. Growth performance and metabolic rates of genetically improved and conventional strains of Nile tilapia, Oreochromis niloticus L., reared individually and fed Ad libitum. In: Proceedings of Sixth International Symposium on Tilapia in Aquaculture. Hrsg: R.B. Bolivar, G.C. Mair and K. Fitzsimmons. Sixth International Symposium on Tilapia in Aquaculture, Manila, Philippines. 379-399 pp.

Mangawaya, C. N. (1986). Influence of methyltestosterone on early growth and sex reversal of Oreochromis niloticus. Port hrcourt- Nigeria. African Regional aquaculture- center. $62 \mathrm{pp}$.

Nuanmanee, P., S. Siangwan and J. Nitharn. 2004. Effects of androgens on sex reversal of Nile tilapia. Fisheries Magazine 57: 251 September 2004.

Pandian , T, J. and Sheela, S.G. (1995). Hormonal induction of sex reversal in fish. Aquaculture, 138: 1-22.

Pantha, B. (1982). The use of soybean in practical feeds for Tilapia niloticus. M. Sc. Thesis. University of Stirling.

Pechsiri, J. and A. Yakupitiyage. (2005). A comparative study of growth and feed utilization efficiency of sex reversed diploid and triploid Nile tilapia, Oreochromis niloticus. Aquaculture Research, 36: 45-51.

Rizkallah, E. H.; Haleem, H. H.; Abdel-halim, A. M. M. and Youssef , R. H. (2004). Evaluation of using 17 A- methyl testosterone for monosex Oreochromis niloticus fry production. J. Egypt. Ger. Soc. Zool. (43A): 315-335.

Saad, M. F. and Samira, S. Rezeka. (1999). Some methods of sex reversal in Oreochromis niloticus with emphasis to possible liver toxicosis. Alex. J. Vet. Sci., 15 (2): - .

SAS Institute (2002). SAS. Software Version 8. SAS Institute Inc, Cary, North Carolina. United States of America.

Soto, P. (1992). Effect of mestanolone (17 $\alpha$-methylandrostan - 17 ß-ol-3-one) on sex ratio and growth of Nile tilapia (Oreochromis niloticus). Masters thesis. Auburn University, Alabama, US : 58 p.

Umberger, E.; Banes, D.; Kunze, F. Sylvia, H.a and Colson, H. (1963). Chemical determination of Diethyl stilboestrol residus in tissues of treated chicken. J. A.O.A.C., 46:441-479. 
Vera Cruz, E.M., and G. C. Mair. (1994). Conditions for effective androgen sex reversal in Oreochromis niloticus (L.) Aquaculture, 122: 237-248.

Vorasayan, P. and N. Petchrich. 2004. Sex Reverse Tilapia Seed Production by using Hormone Mixed Feed. Fisheries Magazine 57: 251 September 2004.

Wichai, T. (1987). Use of methyltestosterone for induced sex reversal and increasing the production of Tilapia nilotica L. Abstract of M Sc. Thesis - fisheris sciense $12: 3$

\section{ARABIC SUMMARY}

\section{انتاج زريعة بلطي وحيد جنس بالتهجين وباستخدام مستويات مختلفة من هرمون V الفا ميثايل تستوستيرون}

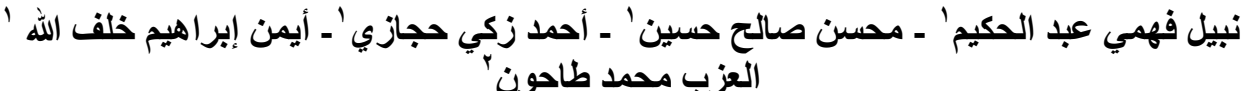

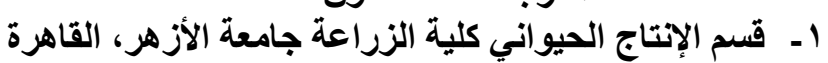

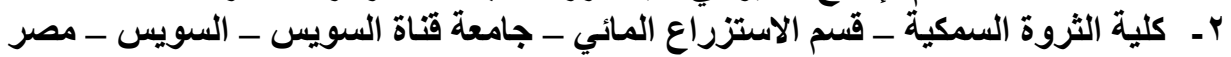

$$
\text { أجريت الاراسة الحالية علي مرحلتين: }
$$

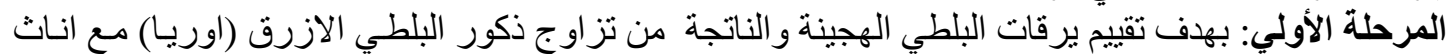

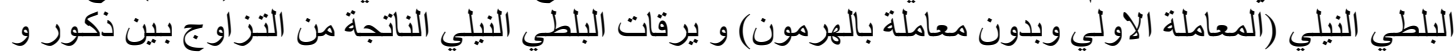

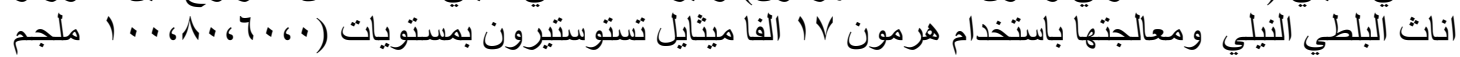

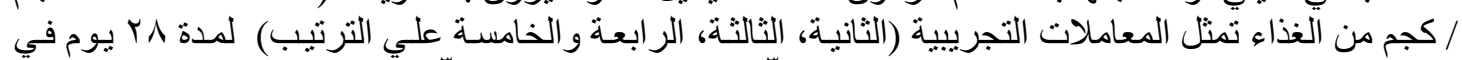

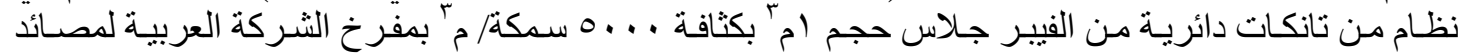
الأسماك بالعباسة_ أبو حماد بائرية من الفافظة الثرقية.

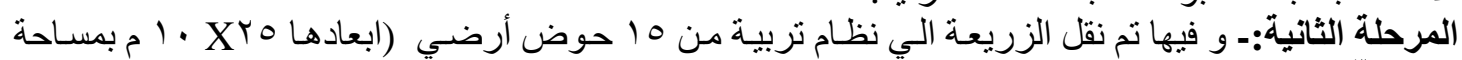

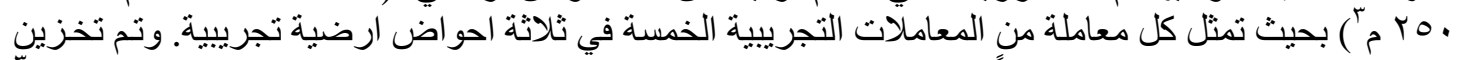

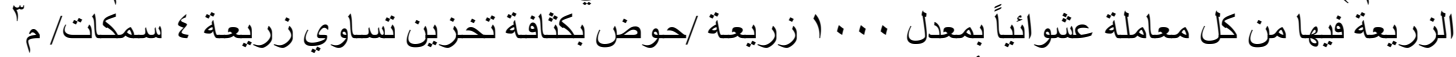

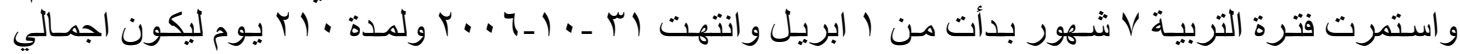

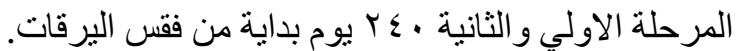

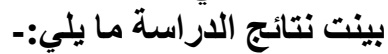

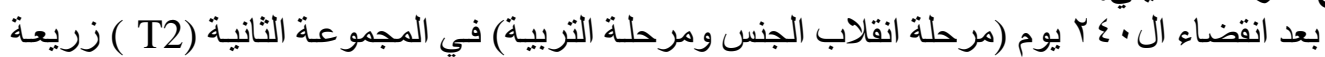

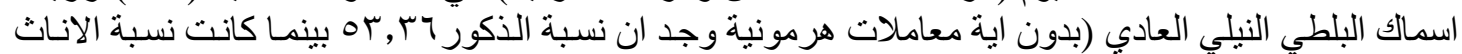

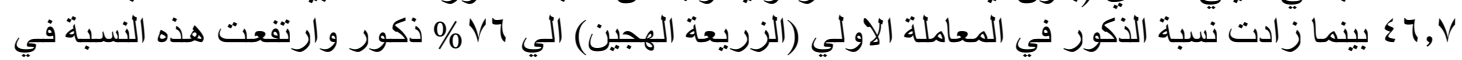

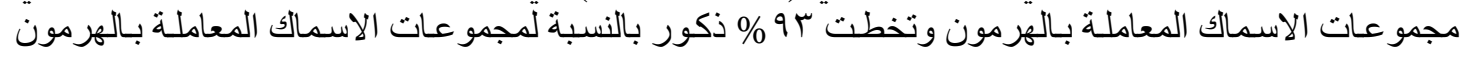

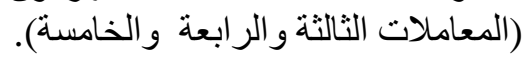

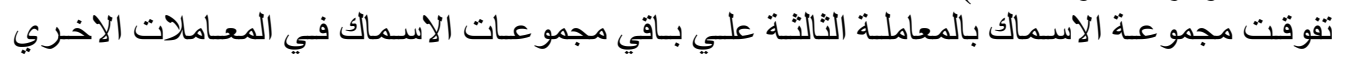

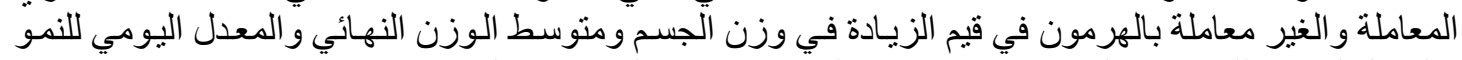

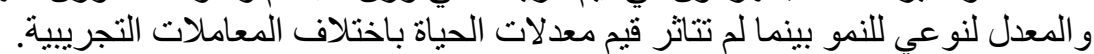

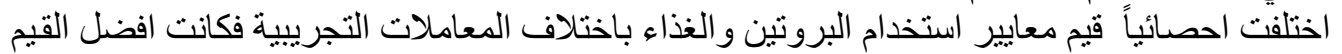

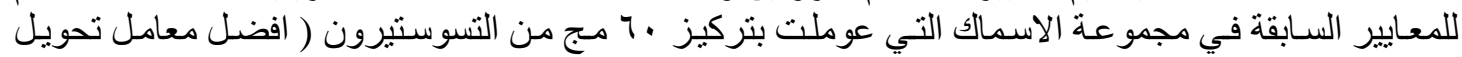

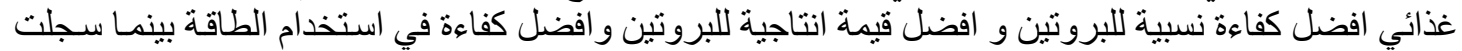

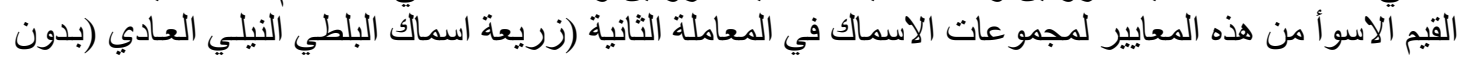

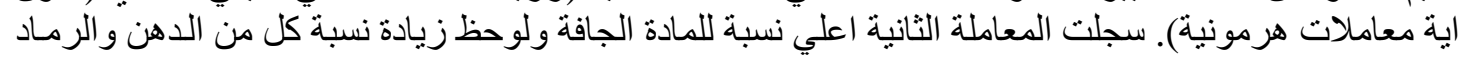

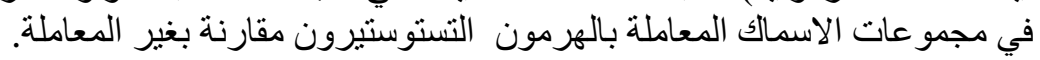

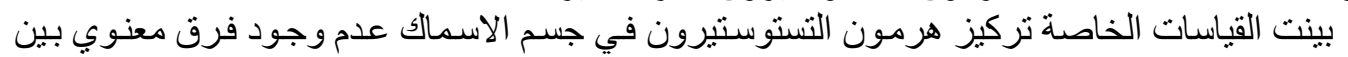

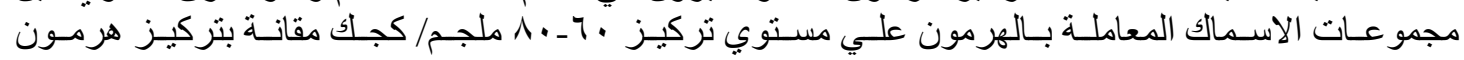

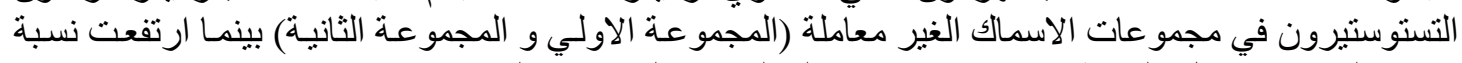
تركيز الهرمون بشكل ملحوظ في مجموعة الاسماك المغذاة علي . . أ ملجم/ كجم تستوستيرون. 